\title{
DOI: 10.17223/9785946217408/410
}

НЕОБЫЧНЫЕ УГЛЕВОДОРОДЫ

${ }^{1}$ Каширцев В.А., ${ }^{2}$ Головко А.К., ${ }^{1}$ Долженко К.В., ${ }^{1}$ Костырева Е.А.

${ }^{1}$ Институт нефтегазовой геологии и геофизики

им. А.А. Трофимука СО РАН, Новосибирск, Россия

${ }^{2}$ ФГБУН Институт химии нефти СО РАН, Томск, Россия

KashircevVA@ipgg.sbras.ru,canc@ipc.tsc.ru

Первоначально «необычные» углеводороды были идентифицированы методом хроматомасс-спектрометрии в хлороформенных экстрактах органического вещества (OB) пермских и каменноугольных отложений сверхглубокой скважины СВ-27 Вилюйской синеклизы (Якутия). Среди проанализированных 70 образцов аргиллитов, начиная с глубины 3387м, эти углеводороды появились в разрезе отложений лишь с глубины около 5,5 км и достигли наибольшей представительности на максимальной глубине в 6458 м [1]. Необычность состава углеводородов заключалась в появлении двух гомологических рядов алкенов-1 и алкенов-3, среди которых первые обладали исключительно нечетным количеством атомов углерода, а вторые - четным. В составе алифатической фракции идентифицированы два гомологических ряда диметилалканов (2,4-Дма, m/z 85) и (2,7-Дма, m/z 127), первый из которых также имел лишь нечетное количество атомов углерода, а второй - четное. Среди ароматических углеводородов определены четыре новых диастереомера - 17-десметил - 23метилмоноароматических стероидов $\mathrm{C}_{27}$ (m/z 366). Рассматривая результаты геохимических исследований всей коллекции образцов, наше внимание привлекло практически полное исчезновение асфальтенов в групповом составе экстрактов на глубинах выше 5 км. Возникло предположение, что «незрелые» углеводороды типа алкенов и других необычных соединений, являются продуктами разрушения асфальтенов, окклюдировавших эти углеводороды на ранних стадиях преобразования органического вещества. Геохимия окклюдированных асфальтенами молекул-биомаркеров и методы их исследования подробно изложена в работе [2].

Для проверки нашего предположения были исследованы хлороформенные экстракты различных по возрасту и фациальной принадлежности кембрийских пород скв. Восток-4 и мезозойских отложений сверхглубокой скв. СГ-6 (Западная Сибирь). К нашему удивлению, во всех этих объектах, там, где породы вошли в зону апокатагенеза, был идентифицирован такой же комплекс «необычных» углеводородов, что и в Вилюйской синеклизе.

В последующем было решено попробовать найти подобные компоненты в слабо литифицированных глинах, где процессы окклюдирования только начинаются. И надо сказать, что одними из первых были обнаружены все четыре диастереомера - 17-десметил 23 -метилмоноароматических стероидов $\mathrm{C}_{27}$, а среди алифатических углеводородов гомологические ряды алкенов с исключительно четным или нечетным количеством атомов углерода и гомологические ряды 2,4- и 2,7-диметилалканов.

Все вышеизложенное вполне однозначно свидетельствует, что комплекс «необычных» углеводородов обязан своим происхождением окклюдированию их асфальтенами на ранних этапах преобразования ОВ и разрушению асфальтенов в зоне апокатагенеза.

Исследование выполнено при финансовой поддержке РФФИ в рамках научного проекта № 18-35-00337

\section{Литература}

1. Kashirtsev V.A., Dolzhenko K.V., Fomin A.N., Kontorovich A.E., Shevchenko N.P. Hydrocarbon composition of bitumen from deeply buried terrestrial organic matter (zone of apocatagenesis) // Russian Geology and Geophysics. - 2017. - Vol. 58. - № 6. - P. 702-710.

2. Snowdon L.R, Volkman J.K., Zhang Z., Tao G., Liu P. The organic geochemistry of asphaltenes and occluded biomarkers // Organic Geochemistry -2016.-Vol. 91-P 3-15. 